\title{
十二指腸蟲ノ經口站二經皮感染二 關スル知見補遺
}

\section{第一編 非固有宿主二經口的二攝取セラレタル 十二指腸蟲仔䖵ノ運命二就テ}

東京帝國大學傳染病研究所 第五研究部寄坐䖵研究察(声任 宮川教授)

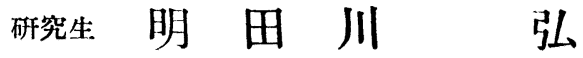

\begin{abstract}
目次
第一章 緒 言

第二章 賽驗材料站二賽驗方法

第一節 十二指腸蟲卵培養法

第二節 十二指腸蟲仔蟲分郁法法

第三節 仔蟲，踰卜感染率

第四節 仔蟲計算法

第五節 動物，俳踰下感染率

第六節 各臟器內二侵入七ル仔䖵分離試驗

第七䇮 氣溫卜感染率

第三章 白鼠二經口的二攝取セシメタル場合 仔蟲, 體内移行状態
\end{abstract}

第一渻 潞取後體内分布狀態卜時䦗的關係 第一項 仔蟲投與後 30 分二於ケル場合 第二項 仔䖪投與後 1 時間二於々ル場合 第三項 仔蟲投與後 5 時間二於々ル場合 第四項 仔蛅投與後 10 時間二於ヶル場 合

第五項 仔蝶投與後 24 時閒二於ヶル場 合

第二節 攝取後體內分布狀態卜各臟器卜， 關係

第一項 胃二於ヶ儿仔蟲，發見率

第二項 晹二於ヶル仔蟲，發見率

第三項 胃卜晹卜二於ヶ $U$ 仔䖵，關係

第四項 肺臟二於ヶル仔䖵，發見䇣
第五項 其/他，臟器二於タル仔蟲，發 見样

第四章 家鬼二經口的二䇠取セシメタル㳟命 仔䖯, 體內移行狀恝

第一節 㩑取後體內分布狀態卜時䦗的關係 第一項 仔蟲投興後 5 时開二於ヶ儿場合 第二項 仔䖵投與後 10 時䦓二於々ル場 合

第三项 仔品投與後 24 胕润三於タル埸 命

第四項 仔螼投興後 48 時閣二於ヶル場 令

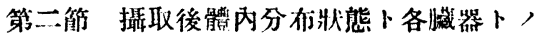
關係

第一項 胃內容卜盟壁卜二於ヶル仔䖵， 發見䇣

第二項 晹內容卜晹壁卜二於々ル仔䖯， 發見率

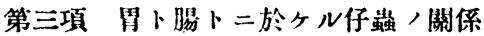

第四項 肺藏二於ヶル仔䖪，發見雰

第五項 其，他，䑏器二於々ル仔蟲，發 見卒

第三節 病理組織學的所見

第五章 總括站二考拨

第六章 結 論

文 部 


\section{第一章 緒 言}

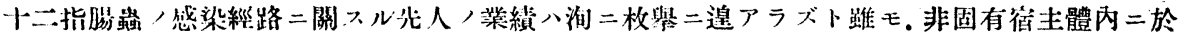

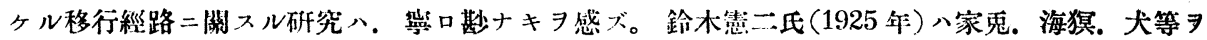

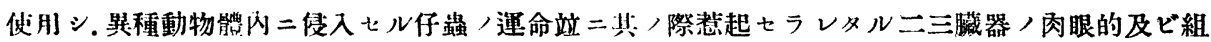

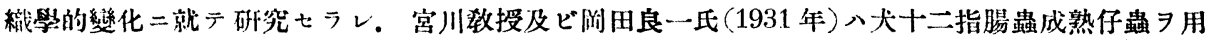

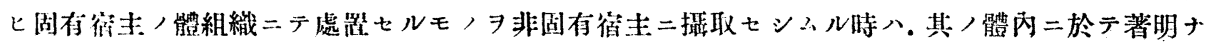

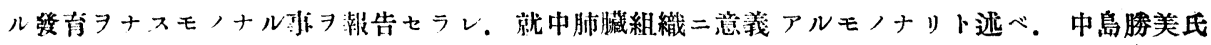
(1932年)モ之レト同㥞ナル成嚗ヨ發表セラレタリ。Sarles 氏 $(1932$ 年)八家鬼习使用シテ仔蟲

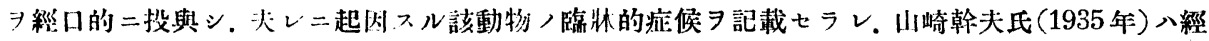

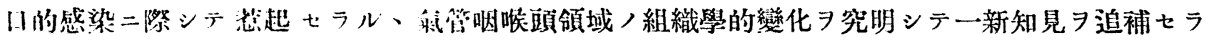

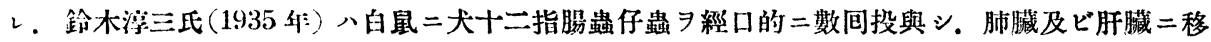

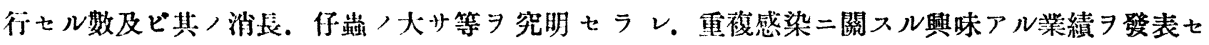

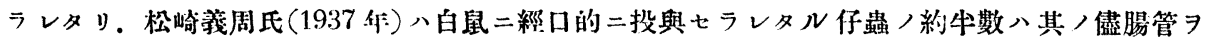

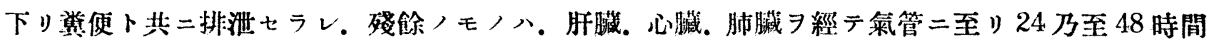

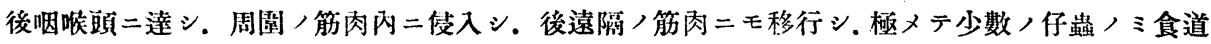

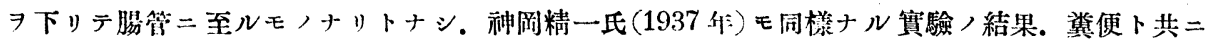

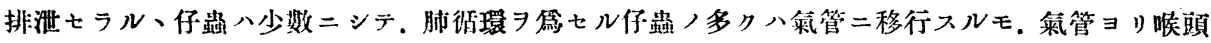
ヨ經テ再ビ消化管二移行ンルモ, 八極メテ少数ナリト述バ，里見暴一郎氏(1937 年)八各種中間

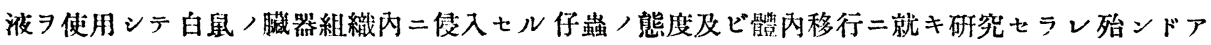

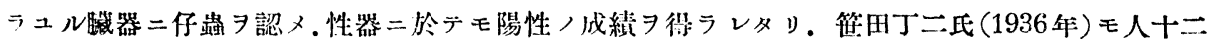

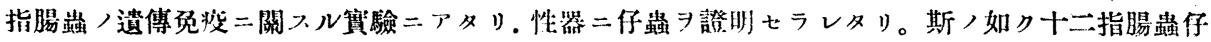
蟲八。經口的タルト經皮的タルト二論ナク殆ンドアラコル臟器。組織二發見七ラル、モノナリ。

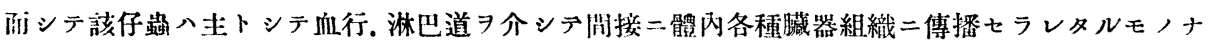

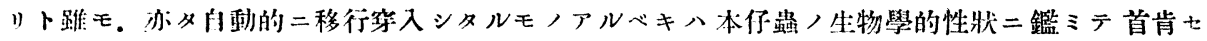

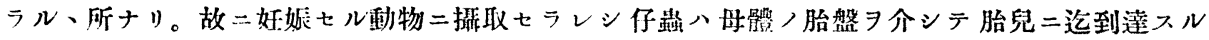
覀ハ可能ナルベシト信ズ。余八富川数授御指導,下二非固有宿主二經口的二攝取セシメタル十

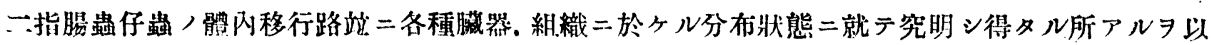

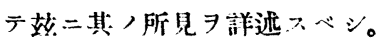

\section{第二章 實驗材料竝二實驗方法}

\section{第一節 十二指晹䖪培鉴法}

十三指腸䖵卵子・初メテ人下们二發有七シメタルハLeukart (1868 年) 氏ナリ。次

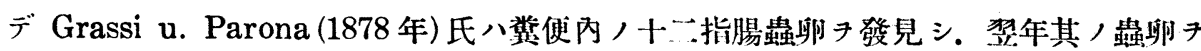

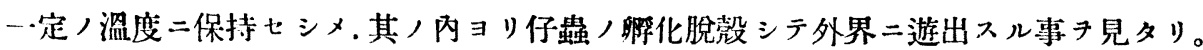
其，後 Perroncito (1882 年). Leichtenstern (1885 年)。Giles (1891-1899 年)。Looss (1897-1905 年)。Bruns (1904 年). Nissele u. Wagner (1904 年)。Fülleborn (1911 
年). Ackert (1922 年)，篠原 (1909 年)，宮川 (1913 年)，大本 (1914 年)，宇佐胃 (1919 年)。濃野 (1928 年)。古山 (1933 年) 氏等二依りテ十二指腸蛍卵培養及ビ發有等二關シ 詳細ナル研究ノ墢表テ見タリ。

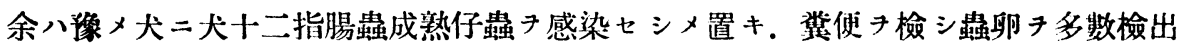

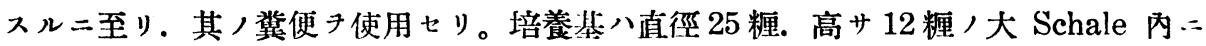

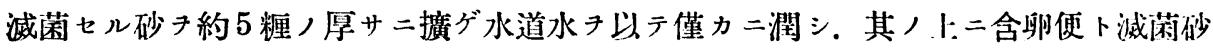

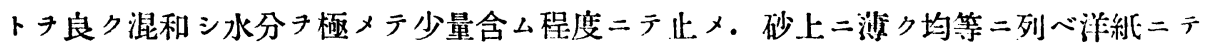
被覆シ。 $28^{\circ} \mathrm{C}$ ，孵卵器內又八 $20^{\circ} \mathrm{C}$ 以上，宗溫二テ滿 5 日閒培養シテ用二供セり。

\section{第二節 仔蟲分離法}

十二指腸蟲仔蟲ヲ分離スルニ八，現今 Baermann 氏法最モ多ク應用セラル。余八 二十餘臺，Baermann 分離裝置ヨ準備シ實驗ニ供セリ．漏斗ハ大小種々ニシテ小ハ

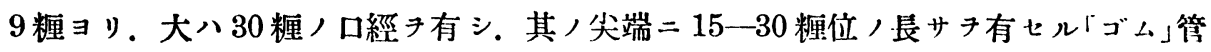
子連結シ Hoffmann 氏鋘ノ代リ二內徑 $1-2$ 粧. 長サ 7-9 糎位, Spitzglass ₹插入

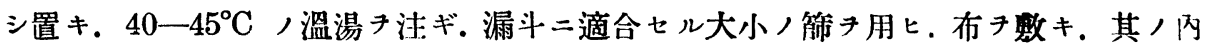
二培養セル砂。 又八可檢組織. 臟器, 細碎片キ入レ Spitzglass 底二集マレル仔蟲子 使用或八检査セり。

\section{第三節 仔䖪／齡卜感染率}

仔蟲, 培養日數ト感染能力トニ關シテハL Looss 氏ハ幼若ナルモノョリ老夦ナルモE 八、方反ッテ皮膚侵入旺盛ナリト云ヒ。明石氏八睬化直後八感染能力ナシト云七。鈴 木憲“氐八幼若ナル仔蟲卜雖モ皮膚軟弱ナル動物二對シテハ容易二侵入スト述べ。 Payne (1923 年) 氏八老龄ナル仔蟲モ感染能力ナキニ非ラザレドモ. 成熟仔蟲 / 其レニ 比スベクモ非ラズト云ヒ，淺田氏八幼若ナル仔䖵モ成蟲トナリ得ベシト云七，白井氏 八老龄ナル仔蟲八榮養顆粒二乏シク感染力弱シト云七。山口操氏ハ培養 6-8 日ガ最 モ適當ナリト述べ，熊谷氏モ之二讚入．笹田氏八培食 7-10日ノモノ最モ感染能力旺 盛ナリト報告七ラル。稻留氏モ實驗き重ネラレ。一般二犬十二指腸蟲仔蟲八感染期二 入リテョリ最初, 7一10日間位が皮膚侵入力最モ旺盛ニシテ. 1 ケ月以媵人モ，八明 ラカ二衰へ，2 ケ月以後二八著シク減弱シ。水中ニアルモノモ土壤中二在ルモノ二於

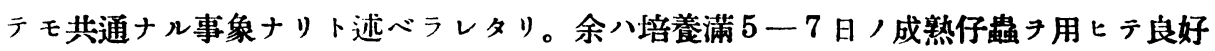
ナル成績キ得タリ。 


\section{第四節 仔䖪計算法}

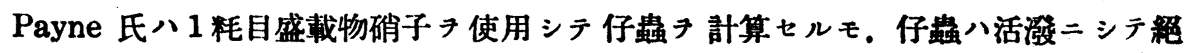

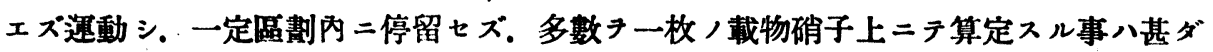
困難ナリ。故二余ハカ、ル方法ハ探ラズシテ.Spitzglass 內二仔蟲水ノ一定量き入レ.

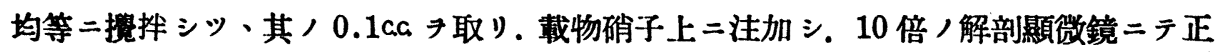
確二數へ。他ノ尖底硝子筒中二移シ。再ビ同樣ナル操作タナシ。之キ數回綝り返シテ

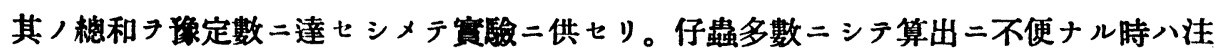
加スル溜水ノ量キ加減セり。數千數萬隻 /名數キ算出スルニアタリ是ノ如キ方法ニテ 八煩雜ナルト．仔䖵ノ運動等ノ障碍二依り時間ノ空費甚ダシク．實際二適セズ．故二

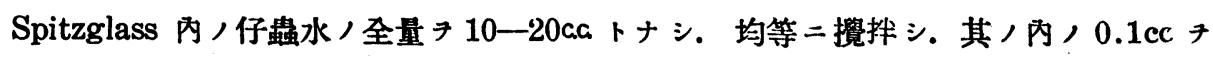

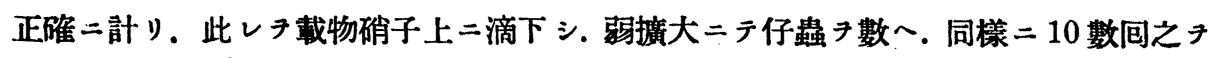

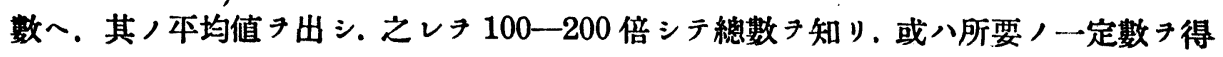
ンガ第メ二幾何量，仔䖵水計ルベキャ等キ算出セリ。

\section{第五節 動物ノ年龄ト感染率}

缩声ノ年龄二關シ. Looss 及ビ Nicoll 氏等八年齡,幼若ナルモノ八老齡ノモノ リモ感染率高ク．體重ノ小ナルモノ八大ナルモノョリモ感染率良好ナリト. Fülleborn (1914 年) 氏ハ初メ認メザルモ1926 年 Strongyloides 二就キ實驗ノ結果暗ニえレ フ認メ. Bruns u. Müller(1905 年)兩氏モ之二䜠シ. Sarles 氏モ Looss 氏ノ說ト一 致セル旨述べラレタリ。山口操氏モ追試セラレテえき認メ. 稻留氏 (1932 年)モ犬二

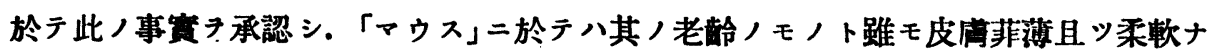
ルキ以テ他ノ專ラ大ナル動物ノ皮㢈キ穿通能力フル仔蟲ニ取りテハ別段二障碍トハナ ラザルモノ、如ク．從ツテ「マウス」ノ年龄ノ多少ニ因ル仔蟲侵入率及八速度ノ差习特 二認ムル能ハズト述べ. 岡田氏ハ幼年犬二比シ老年犬八感染率低シト云七。笹田氏ハ 「マウス」ノ體重 30 瓦以內ノモノニ於テ仔蟲ハ肺臟へノ移行率最モ高ク. 50 瓦以上ハ 最モ低キヨリ見テ幼若且.體重小ナルモノ程感染率高シト報告セリ。

\section{第六節 各脿器內二侵入セル仔蟲分離試驗}

Baermann 氏分焳装置ハ十二指腸䖵成熟仔蟲 越向性 (Tropismus) チ巧二利用シテ

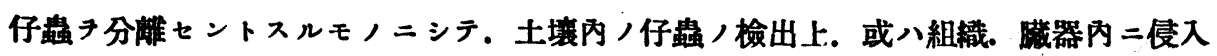




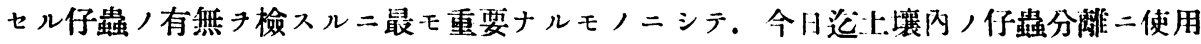
シ. 又其ノ分離率二就キ研究七儿學者 (Baermann, Cort u. Augustine, Fülleborn, 橫川. 本井)多ケレドモ。乙チ利用シテ各臟器內二侵入七ル仔蟲，分離狀態及ビ適否 等二就キ研究セル者無キガ如キキ以テ，余ハ本問題二就キ二三ノ實驗フ試にタリ。十

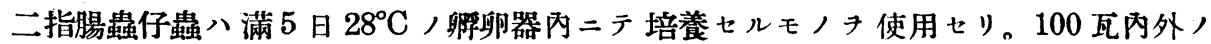

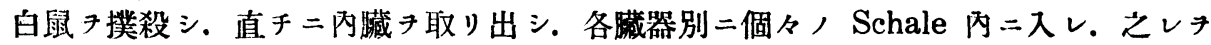

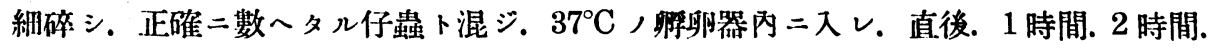
5 時間卜時間的ニ取り出シ. Baermann 氏装置キ應用シテ仔蟲/分離狀態子調查七 リ。第 1 表二示ス如ク。仔蟲投入直後二於テ八肺藏最モ分雖良好ニシテ $95 \%$ フ認メ. 腸管及ビ肝藏八略?同成績ニシテ $40 \%$ 內外ヌ示シ。胃二於テ八分陮最モ不良ニシテ

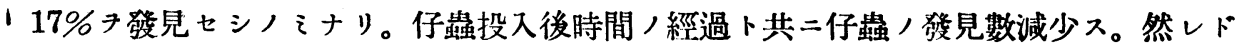

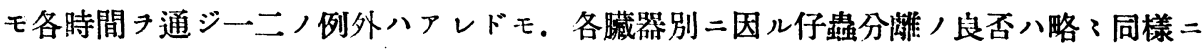

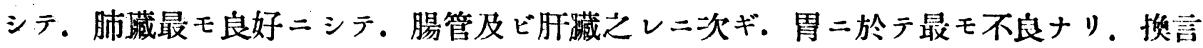
スレバ胃二於テ最モ侵入率良好ナリトモ云ヒ得べク．肺藏ニ於テハ仔蟲通過二最モ容

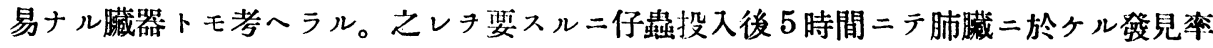
ガ本均 $59.3 \%$ ニテそレガ最高ナル事ヨリ見ルモ Baermann 氏装置が尙木理想的 ノモノニアラザルハ言キ俟タズ。

第 1 表 剔出矌器二於ケル仔蛊，發見集

\begin{tabular}{|c|c|c|c|c|c|c|c|}
\hline 實驗日 & 實驗番號 & $\begin{array}{l}\text { 䔬驗動 } \\
\text { 體重 }\end{array}$ & 經過時 & 肺 臟 & 腸 & 胃 & 肝 搭 \\
\hline $1 / \mathrm{VII}$ & 113 號 & $75 \mathrm{gm}$. & 直 後 & $94.7 \%$ & $43.1 \%$ & $16.7 \%$ & $40.2 \%$ \\
\hline 9/VII & 119, & 110 & 1 時間 & 68.5, & 38.3 ," & 8.9, & 24.2, \\
\hline 19/V 倓 & 128, & 160, & 2 時間 & 41.1, & $34: 5$, & 34.5, & 30.3, \\
\hline 19/VII & 127, & 110, & 5 時間 & $\begin{array}{l}72.3, " \\
46.3 . \\
\end{array}$ & $\begin{array}{l}35.2, " \\
41.5 . \\
\end{array}$ & $\begin{array}{l}7.4, " \\
7.6, " \\
\end{array}$ & $\begin{array}{l}29.4, " \\
26.7, "\end{array}$ \\
\hline
\end{tabular}

\section{第七節 氣溫卜感染率}

曾ツテ Looss 氏ハ氣溫ト仔蟲卜ノ運動ハ密接ナル關係キ有シ $30-38^{\circ} \mathrm{C}$ チ最モ適常 ト第スト云ハレタル事アリ。

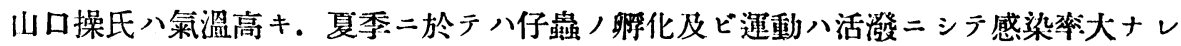
ドモ低溫ナル冬季ニ於テハ之レニ反シ感染率小ナリト，但シ經口的感染二八無關係ナ リト謂ヘリ。江口氏ハ冷血動物及ビ死動物ニモ仔䖵/侵入可能ナル事實キ擧ゲテ。

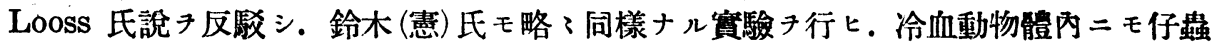
ル侵入八可能ナレドモ溫血動物二比シ造カ二尠ナク．體溫，消失又八低下八仔蟲侵入 
フ困難ナラシムル・ヒノニシテ.日光ノ有無二八無關係ノモノ、如ク氣溫ノ高低二左右 セラル、モノニシテ春夏秋ョ最モ適當トスト述心゙。艘留氏ハ「マウス」ニ就テ, 賽驗ノ 結果. Looss 氏說二詯スレドモ. $20^{\circ} \mathrm{C}$ 以下, 比較的二低溫度二於テモ「マウス」ハ割合 二良ク感染スルコトヨリ見ルE. 感染八等口「マウス」ノ體表, 溫度ノ高低如何二因ル 影慗がヨリ著シキモモノ有ルキ認メタリト。

\section{第三草 白鼠二經口的感染ヨ行ヒタル場合ニ於ケル 仔蟲ノ體內移行狀態}

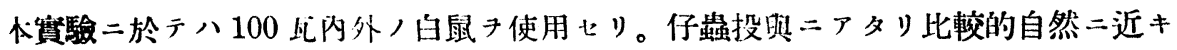
狀態ニテ感染七シメントシ. 璸驗前動物キ. 空腹トナサシメ. 正確二數へタル仔蟲水 7. Pipette ニテ. 其ノリ中 1 滴ヅ、滴下七シメ. 仔蟲ノ殘留七ルモノナキ樣注意

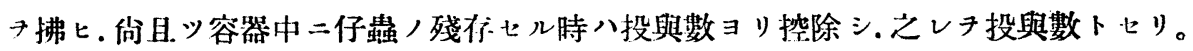

投與後 30 分. 1 時間. 5 時間. 10 洔間. 24 時間ト時間的二撲殺シ. 直チ二內臟き 取り出シ. 食道. 胃. 腸. 心筋及ビ心內血液. 肺臟. 其, 他八臟器ト二區分シ. 各臟

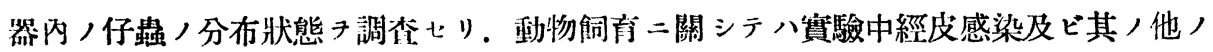

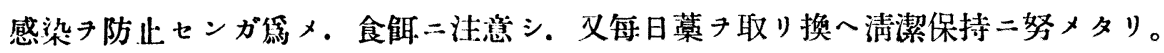

\section{第一節 攝取後體內分布狀態卜時間的關係}

\section{第一項 保投與後 30 分二於ケル場合}

仔蟲投與後 30 分二於テ八其ノ大部分八胃二於テ發胃セラレ.腸二於テハ僅カ二發見

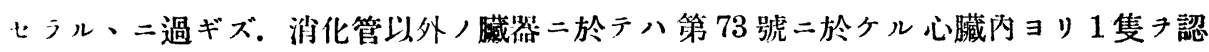
メジンナリ。(第 2 表)

第 2 表 仔蟲投與後 30 分二於ヶル仔蟲發見率(白鼠)

\begin{tabular}{|c|c|c|c|c|c|c|c|c|c|c|c|c|}
\hline $\begin{array}{l}\text { 筫 } \\
\text { 日 } \\
\text { 裣 } \\
\text { 日 }\end{array}$ & $\begin{array}{l}\text { 筫及 } \\
\text { 礆 } \\
\text { 番 } \\
\text { 號性 }\end{array}$ & $\begin{array}{l}\text { 筫體 } \\
\text { 铪 } \\
\text { 動 } \\
\text { 物重 }\end{array}$ & $\begin{array}{l}\text { 投 } \\
\text { 與 } \\
\text { 仔 } \\
\text { 蛊 } \\
\text { 卙 }\end{array}$ & $\begin{array}{l}\text { 投見 } \\
\text { 與迄 } \\
\exists> \\
\text { リ時 } \\
\text { 剖閒 }\end{array}$ & 道 & 胃 & 腸 & 肺 & 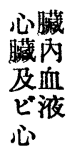 & 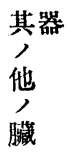 & $\begin{array}{l}\text { 總 } \\
\text { 發 } \\
\text { 見 } \\
\text { 數 }\end{array}$ & $\begin{array}{l}\text { 投ス } \\
\text { 與N } \\
\text { 數百 } \\
\text { =分 } \\
\text { 對率 }\end{array}$ \\
\hline $20 / \mathbb{1}$ & 73 & $87 \mathrm{gm}$. & 900 & 30 分 & 0 & 194 & 39 & 0 & 1 & 0 & 234 & $26.0 \%$ \\
\hline $27 / \mathrm{IV}$ & 80 ๙ิ & 65, & 950 & ", & 0 & 152 & 52 & 0 & 0 & 0 & 204 & 21.4, \\
\hline $26 / \mathrm{IV}$ & 93 & 100, & 960 & " & 2 & 281 & 32 & 0 & 0 & 0 & 313 & 32.6, \\
\hline
\end{tabular}

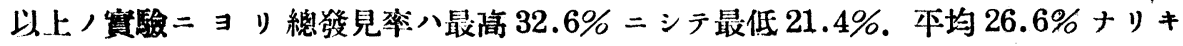


(以下\%八投與數二對スル仔蟲發見數ノ百分率トス)

\section{第二項 仔䖪投與後 1 時間二於ケル坦合}

仔蚎投與後 1 時間二於テハ 30 分二於ケルト同㥞. 胃二最モ多ク. 次二腸ニ於テ之 レナ認メ。食道ニ於テ 1 例 4 隻テ認メシノミナり。第 3 表ノ如ク總發見率ハ最高 78.7 $\%$ ニシテ最低 $34.6 \%$ ．本均 $57.6 \%$ ナリ。Scott 氏ノ成績二体レバ最高 $66 \%$ ，最低

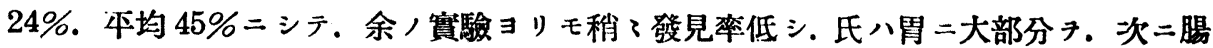
二於テ仔蟲き發見セリト述べ。 1 例二於テハ肺臟ニ 3 隻. 肝臟二1隻き認メシノミト 報告セり。里見氏八肝臟二於テ $0.2 \%$. 胃壁二 $0.2 \%$ 小腸壁二 $0.4 \%$ キ認メシノをナ リト。(第 3 表)

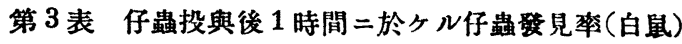

\begin{tabular}{|c|c|c|c|c|c|c|c|c|c|c|c|c|}
\hline $\begin{array}{c}\text { 賽 } \\
\text { 驗 } \\
\text { 日 }\end{array}$ & $\begin{array}{l}\text { 菑號 } \\
\text { 験及 } \\
\text { 動ビ } \\
\text { 物性 } \\
\text { 番別 }\end{array}$ & $\mid \begin{array}{l}\text { 賽體 } \\
\text { 殹 } \\
\text { 動 } \\
\text { 物重 }\end{array}$ & $\begin{array}{l}\text { 投 } \\
\text { 與 } \\
\text { 仔 } \\
\text { 蟲 } \\
\text { 数 }\end{array}$ & $\begin{array}{l}\text { 投見 } \\
\text { 與迄 } \\
\text { ヨ父 } \\
\text { リ時 } \\
\text { 剖間 }\end{array}$ & 食 & 胃 & 腸 & 肺 & $\begin{array}{l}\text { 心脿 } \\
\text { 篫內 } \\
\text { 及血 } \\
\text { ヒ液 } \\
\text { 心 }\end{array}$ & $\begin{array}{l}\text { 其器 } \\
\text { 他 } \\
\text { 懗 }\end{array}$ & $\begin{array}{l}\text { 總 } \\
\text { 繁 } \\
\text { 見 } \\
\text { 數 }\end{array}$ & $\begin{array}{l}\text { 投 } \\
\text { 舆 } \\
\text { 數百 } \\
=\text { 分 } \\
\text { 對率 }\end{array}$ \\
\hline 23/III & 74 우 & $65 \mathrm{gm}$ & 910隻 & 1 時間 & 4 & 502 & 35 & 0 & 0 & 0 & 541 & $59.4 \%$ \\
\hline 8/IV & 84 오 & 70, & 949, & ", & 0 & 323 & 6 & 0 & 0 & 0 & 329 & 34.6. \\
\hline $20 / \mathrm{VI}$ & $109 \hat{\delta}$ & 100, & 1479, & " & 0 & 571 & 593 & 0 & 0 & 0 & 1164 & 78.7 \\
\hline
\end{tabular}

\section{第三項 仔是投與後 5 時間二於ケル場合}

仔蟲投與後 5 時間二於テモ前記，場合卜略 、同樣ニシテ胃. 腸二於テ多數發見七ラ レ. 1 例ニ於テ食道二 4 隻. 消化管以外, 蓇器二於テ 1 隻キ認メタリ。總發見率八最 高 $65.0 \%$ ，最低 $48.1 \%$ ．本均 $55.8 \%$ ナリキ。(第 4 表)

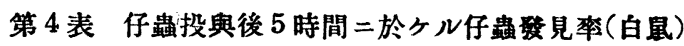

\begin{tabular}{|c|c|c|c|c|c|c|c|c|c|c|c|c|}
\hline $\begin{array}{l}\text { 夤 } \\
\text { 険 } \\
\text { 日 }\end{array}$ & $\begin{array}{l}\text { 害號 } \\
\text { 驗及 } \\
\text { 勳ビ } \\
\text { 物性 } \\
\text { 番別 }\end{array}$ & $\begin{array}{l}\text { 實體 } \\
\text { 驗 } \\
\text { 動 } \\
\text { 物重 }\end{array}$ & $\begin{array}{l}\text { 投 } \\
\text { 與 } \\
\text { 仔 } \\
\text { 趩 } \\
\text { 數 }\end{array}$ & $\begin{array}{l}\text { 投見 } \\
\text { 與迄 } \\
\text { ヨ人 } \\
\text { リ時 } \\
\text { 剖間 }\end{array}$ & 道 & 胃 & 腸 & 戥 & 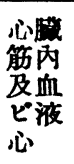 & 其器 & 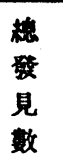 & $\begin{array}{l}\text { 投ス } \\
\text { 舆 } \\
\text { 數百 } \\
=\text { 分 } \\
\text { 對 }\end{array}$ \\
\hline 22/III & 75 우 & $75 \mathrm{gm}$ & 920隻 & 5 時間 & 4 & 400 & 42 & 0 & 0 & 1 & 447 & $48.1 \%$ \\
\hline $3 / \mathrm{V}$ & 96 今 & $90 "$ & 980 & " & 0 & 425 & 212 & 0 & 0 & 0 & 637 & 65.0. \\
\hline $27 / \nabla$ & 100 今 & $80 "$ & 930, & ," & 0 & 432 & 72 & 0 & 0 & 0 & 504 & 54.2, \\
\hline
\end{tabular}

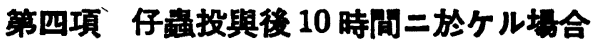

仔蟲投與後 10 時間二於テモ佾木胃二於テ最モ多ク發見七ラレ. 次二腸二於テ比较 的多數，仔䩶認メ。其，他食道二於テ僅カ二仔蟲子發見七り。總發見率八最高 38.8 
$\%$ ニシテ最低 $19.8 \%$ ．本均 $28.7 \%$ ナリキ。(第 5 表)

第 5 表 仔蟲投與後 10 時閒二於ヶル仔蟲發見率(白鼠)

\begin{tabular}{|c|c|c|c|c|c|c|c|c|c|c|c|c|}
\hline $\begin{array}{l}\text { 實 } \\
\text { 䛈 } \\
\text { 日 }\end{array}$ & 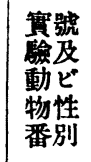 & $\begin{array}{l}\text { 賽體 } \\
\text { 铪 } \\
\text { 動 } \\
\text { 物重 }\end{array}$ & $\begin{array}{l}\text { 投 } \\
\text { 與 } \\
\text { 蛊 } \\
\text { 數 }\end{array}$ & 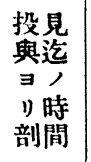 & 道 & 胃 & 腸 & 戥 & $\begin{array}{l}\text { 心臓篫 } \\
\text { 血液 } \\
\text { 心 }\end{array}$ & $\begin{array}{l}\text { 其器 } \\
\text { 他 } \\
\text { 臟 }\end{array}$ & $\begin{array}{l}\text { 總 } \\
\text { 策 } \\
\text { 見 } \\
\text { 數 }\end{array}$ & $\begin{array}{l}\text { 投元 } \\
\text { 與岀 } \\
\text { 數貧 } \\
\text { 對率 }\end{array}$ \\
\hline $25 / \mathbb{R}$ & 76 今 & $80 \mathrm{gm}$. & 995隻 & 10時間 & 2 & 156 & 39 & 0 & 0 & 0 & 197 & $19.8 \%$ \\
\hline $27 / \nabla$ & $101 \hat{\delta}$ & 85, & 1000, & ", & 0 & 315 & 73 & 0 & 0 & 0 & 388 & 38.8, \\
\hline $27 / \mathrm{V}$ & $103 \hat{\delta}$ & 75, & 1000, & , & 0 & 179 & 95 & 0 & 0 & 0 & 274 & 27.4 , \\
\hline
\end{tabular}

\section{第五項 仔蟲投與後 24 時間二於ケル場合}

仔蟲投與後 24 時間二於テハ肺臟二於テ。最モ多ク發見セラレ。次二腸. 胃. 其レ以 外,臟器ノ順序トナル。

第 6 表 仔蟸投與後 24 時間二於ヶル仔蟲發見率(白鼠)

\begin{tabular}{|c|c|c|c|c|c|c|c|c|c|c|c|c|}
\hline $\begin{array}{l}\text { 算 } \\
\text { 跧 } \\
\text { 日 }\end{array}$ & $\begin{array}{l}\text { 寒號 } \\
\text { 動 } \\
\text { 物性 } \\
\text { 番別 }\end{array}$ & $\begin{array}{l}\text { 菑體 } \\
\text { 驗 } \\
\text { 動 } \\
\text { 物重 }\end{array}$ & $\begin{array}{l}\text { 投 } \\
\text { 與 } \\
\text { 仔 } \\
\text { 贵 } \\
\text { 數 }\end{array}$ & $\begin{array}{c}\text { 投見 } \\
\text { 與迄 } \\
\text { ヨ分 } \\
\text { リ時 } \\
\text { 剖閒 }\end{array}$ & 道 & 盟 & 腸 & 肺 & $\begin{array}{l}\text { 心臟 } \\
\text { 筋内 } \\
\text { 及血 } \\
\text { ビ液 } \\
\text { 心 }\end{array}$ & 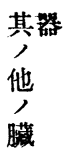 & $\begin{array}{l}\text { 總 } \\
\text { 發 } \\
\text { 見 } \\
\text { 數 }\end{array}$ & $\begin{array}{l}\text { 投ス } \\
\text { 與公 } \\
\text { 數百 } \\
\text { 分 } \\
\text { 對率 }\end{array}$ \\
\hline 28 '任 & $77 \hat{\delta}$ & $65 \mathrm{gm}$. & 1000 隻 & 24時開 & 1 & 21 & 113 & 115 & 1 & 17 & 26. & $26.8 \%$ \\
\hline $8 / \mathrm{IV}$ & 85우 & 67 " & 970 & " & 0 & 68 & 14 & 189 & 1 & 4 & 417 & 42.9 \\
\hline $3 / V$ & $97 \hat{\delta}$ & $90 \ldots$ & 930, & ", & 0 & 37 & 106 & 148 & 0 & 48 & 335 & 36.1 , \\
\hline
\end{tabular}

鈴木淳三氏 成績二因レバ肺藏. 肚臟二於ケル發見率ノ最高ハ $45.9 \%$. 最低ハ 37.2 $\%$ ニシテ. Scott 氏ノ報傕二因レバ 24 時間二於テ胃二最モ多ク. 次二小腸. 盲腸二 發見スルモノ多ク．肺藏及ビ朋臟二發見七ルモ，八比較的尠ナク．總發見率八平均 $36 \%$ ナト．里見氏八左右兩肺臟ヨリ $6 \%$ フ認メ。神岡氏八肺藏二最モ多數發見七ラ ル、八投與後 $26-30$ 時間ニシテ $12-26 \%$ フ發見セりト云七。余/實驗二於テハ左右 兩肺䑏ヨリ最高 $19.5 \%$ 7。最低 $11.5 \%$. 本均 $15.6 \%$ 發見シ。總發見率ハ最高 42.9 $\%$ ．最低 $26.8 \%$ ．平均 $35.3 \%$ ナリキ，(第 6 表)

\section{第二節 攝取後體內分布狀態卜各臟器トノ關係}

\section{第一項 国二於ケル仔题ノ墢見率}

胃二於テ發胃セラル、仔蟲數八投與後 30 分二於テ最高 $29.0 \%$. 最低 $16.0 \%$ テシテ 本均 $22.3 \%$ ナリ，投與後 1 時間二於テ最高 $55.2 \%$. 最低 $34.6 \%$ ニシテ本均 $42.6 \%$ す 
第 7表 白鼠，胃二於ヶル仔䖵發見率

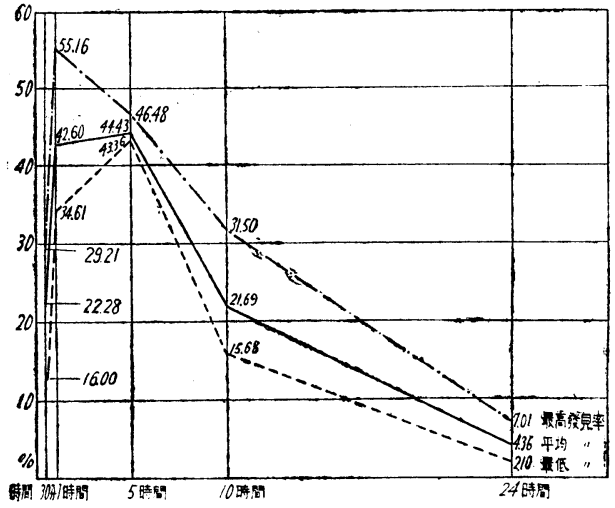

第 8 表 白星，腸二於ヶル仔䖵發見钭

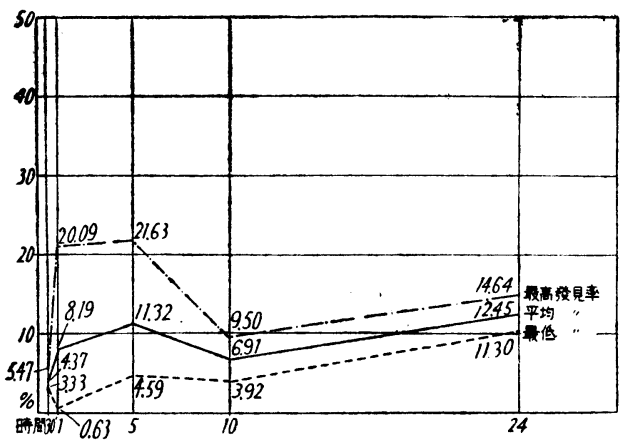

第 9 表 白鼠，胃卜腸二於ヶル仔䖵繁見

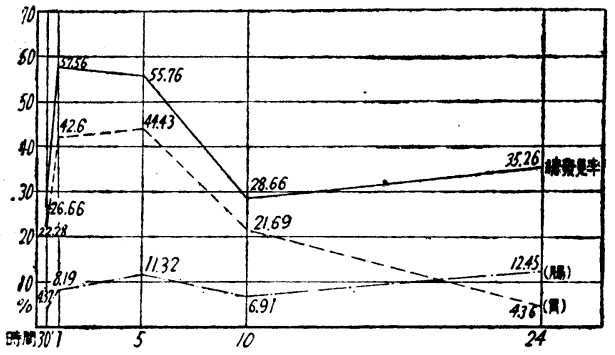

リ。投與後 5 時間二於テ最高 $46.5 \%$ 。 最低 $43.4 \%$ ニシテ本均 $44.4 \%$ ナ。 投與後 10 時間二於テ最高 $31.5 \%$.最 低 $15.7 \%$ ニシテ本均 $21.7 \%+リ 。$ 投興後 24 時間二於テ最高 $7.0 \%$ 。最 低 $2.1 \%$ ニシテ本均 $4.4 \%+リ 。 以 ~$ 上，實驗二於テ 時間的二發見良好ナ ル・ヒノヨリ列記七バ。 5 時間一 1 時 間-30分- -10 時間-24 時間,順序 卜 ナル．そレキ曲線ニテ示セバ第 7 表 ノ如シ。

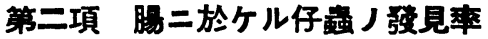

腸二於テ八仔蟲投與後 30 分ニシテ本 均 $4.4 \%$ 認メ。1 時間二於テ $8.2 \%$ 尹. 5 時間二於テ $11.3 \%$. 10 時間二 於テ $6.9 \% .24$ 時間二於テ $12.5 \%$ ヲ 發胃七り。郎于投與後仔蟲八時間的 二多少，消長ハアレドモ。概ネ 24 時 間迄腸二於テ增加ノ傾问テ示ス。之 レタ曲線ニテ示セバ第 8 表ノ如シ。

\section{第三項 胃卜睓卜ニ於ケル} 仔题閐你

投與セ儿仔蟲ハ胃二於テ' 5 時間目 二最高二達シ. 以後減少スル二反シ。 腸二於テ八 10 時間二於テ例外的二發 見率不良ナルモ。其ノ他ノ時間二於 テハ漸次增加シ 24 時閒二於テ最高二

達セリ。之レキ曲線ニテ示セバ第 9 表ノ如シ。

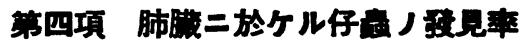

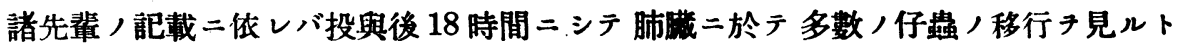
云フ。18 時間以前二於テ里見氏，䐵驗二依レバ經皮的感染／場合. 投與媵 6 時間ニシ 


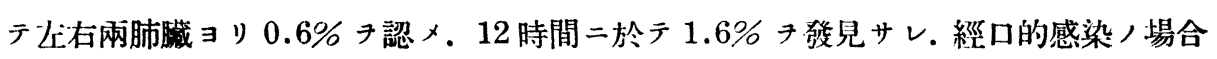
二於テ投與後 6 時間 ニシテ右肺臟ヨリ $0.2 \%$ キ認メ. 12 時間二於テ左右兩肺臟 ヨリ $0.8 \%$ 發塄シ. 24 時間二於テ $6 \%$ 證明シ。同時間二於テ經皮的感染，場合ハ 13.6

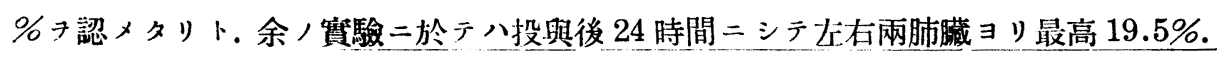
最低 $11.5 \%$ 。本均 $15.6 \%$ チ發見シ。10時間以前ニ於テ八‥隻モ發見スル事キ得ザリ

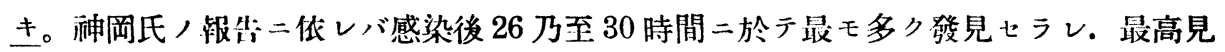

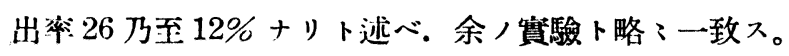

\section{第五項 其ノ他臟器二於ケル仔䗝ノ發見率}

前逃以外，臟器二於テ弡兒七ラル、仔䖵數ハ比較的少ナシ。投與後 24 時間上前二

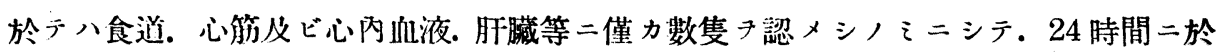
テ初メテ投與數, $2.5 \%$ 發見七り。

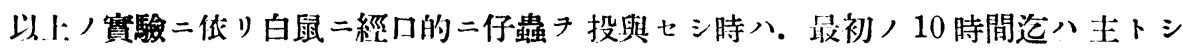
テ消化管二於テ， $i$ 仔蟲 認メ. 消化管以外二於テハ殆ンド仔蟲キ認メズ. 胃及ビ腸 二於ヶル仔蟲，消長キ見ル二．胃二於テハ投與後 5 時間二於テ本均 $44.4 \%$ 認メ. 全時間キ道ジ最高キ示シ。爾後漸次減少シ. 24 時間二於テ $4.4 \%$ 發見七シニ過ギ ズ。腸二於テ八時間ノ經過卜共卜溸次增加シ。 24 時間二於テ $12.5 \%$ 發見セリ。投 與後 24 時閒二於テ初メテ消化管以外, 藏器 $コ$ 多數, 仔蟲キ認メ。最モ多數キ發見 七シ八肺藏ニシテ本均 $15.6 \%$ 子認メ。其,他，臟器二於テハ本均 $3.6 \%$ 發見七 リ。

\section{第四章 家鬼二經口的二掫取セシメタル場合 仔蟲ノ體內移行狀態}

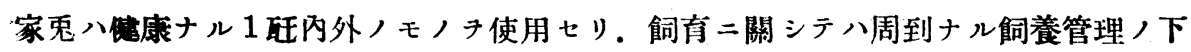

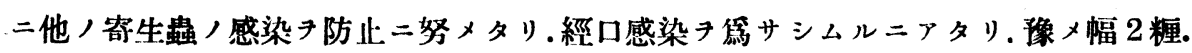
長サ 5 粝位, 薄キ木片ノ中央二直徑 1 糎位ノ穴キ穿チ. 之レチ家鬼ノ口中二插入シ。 其ノ穴キ利用シテ. Pipette ニテ仔蟲含有水テ滴下シ投與七リ。或ハ又豆腐涬等/中 二混ジテ投與セル場合アリ．先人ノ多クハ「カテーテル」テ用七．直接胃內二仔䖵注 入セラレタルモ。余八比較的自然二近キ方法キ以テ感染セシメントシ。斯ノ如キ方法 キ試にシナリ。

斯クシテ經口的二投與七シ後。 5 時間. 10 時間. 24 時間. 48 時間卜各時間每二家

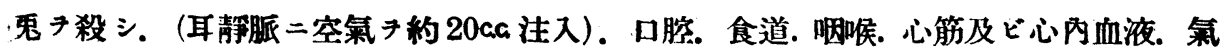




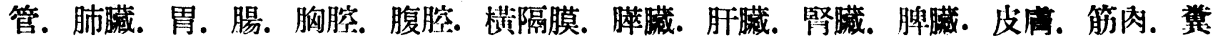
便內等二就キ仔蟲ノ有無キ精查セリ.各組織.贜器. 冀便等ハシレキ細碎シ. Baermann

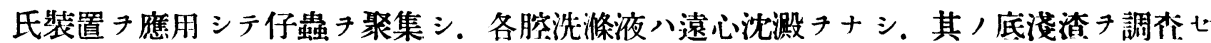
リ。

\section{第一節 攝取後體內分布狀態卜時間的關係}

\section{第一項 仔蟲投與啳 5 時間二於ケル埸合}

仔蟲投與後 5 時間二於テハ胃二最モ多ク次二腸二發見サレ。其レ以外二於テ肺臟卜

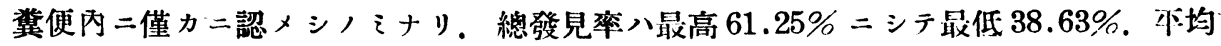
$52.05 \%+リ 。($ 第 10 表)

第 10 表 仔蟲投與後 5 時間二於クル仔蟲發見率(家鬼)

\begin{tabular}{|c|c|c|c|c|c|c|c|c|c|}
\hline 實 驗 & 日 & $15 / \mathrm{VI}$ & $7 / \mathrm{VII}$ & $19 / \mathrm{VII}$ & 實 & 日 & $15 / \nabla I$ & $7 / \mathrm{VW}$ & $19 / \mathrm{VII}$ \\
\hline \multirow{2}{*}{\multicolumn{2}{|c|}{ 動 物 番 號 }} & 白 + + & 白 + 早 & 白 우 & \multirow[b]{2}{*}{ 小 腸 壁 } & 上部 & 172 & 15 & 645 \\
\hline & & 108 & 170 & 174 & & 下部 & 1126 & 18 & 912 \\
\hline 動 物 骨 & 重 & 1800 & 1110 & 1300 & \multirow{2}{*}{ 大 } & 內 & 67 & 4 & 15 \\
\hline \multicolumn{2}{|c|}{ 投與 仔蟲 數 } & 10000 & 6800 & 9600 & & 壁 & 144 & 5 & 96 \\
\hline \multicolumn{2}{|c|}{ 投與ヨリ剖見迄ノ時間 } & 5 & 5 & 5 & 胸 & 內 & 0 & 0 & 0 \\
\hline \multicolumn{2}{|l|}{ 口腔 } & 6 & 2 & 8 & 腹 & 內 & 0 & 0 & 0 \\
\hline \multicolumn{2}{|l|}{ 口腔 } & 35 & 5 & 16 & 橫 & 膜 & 0 & 0 & 0 \\
\hline \multicolumn{2}{|l|}{ 食 } & 5 & 6 & 8 & 膵 & 臟 & 0 & 0 & 0 \\
\hline \multicolumn{2}{|c|}{ 心萠及ビ心缄內血液 } & 0 & 0 & 0 & 肝 & 臟 & 0 & 0 & 0 \\
\hline \multicolumn{2}{|c|}{ 氣 } & 0 & 17 & 13 & 雨 & 誡 & 0 & 0 & 0 \\
\hline \multirow{2}{*}{ 肺搭 } & 右 & 0 & 6 & 2 & 脾 & 臟 & 0 & 0 & 0 \\
\hline & 左 & 0 & 27 & 4 & 皮 & 雷 & 0 & 0 & 0 \\
\hline \multirow{2}{*}{ 胃 } & 內 & 962 & 1799 & 1751 & 筋 & 內 & 0 & 0 & 0 \\
\hline & 壁 & 1031 & 1886 & 1428 & 糞 & 便 & 0 & 1 & 6 \\
\hline \multirow{2}{*}{ 小腸 内 } & 上部 & 48 & 17 & 295 & 總 䇾 & 見 數 & 3863 & 3826 & 5880 \\
\hline & 下部 & 297 & 18 & 681 & 投與数=對 & 几百分星 & $38.63 \%$ & $56.26 \%$ & $61.25 \%$ \\
\hline
\end{tabular}

\section{第二項 仔螆投興啳 10 時間二於ヶル場合}

仔蟲投與後 10 時間二於テハ 5 時間二於ケルト同樣. 胃二鼠モ多クキ認メ.次二小腸. 大腸. 食道等，順序トナリ， 口膑. 霬便內二僅カ二發見ス。總發見來八最高 $56.66 \%$. 最低 $28.42 \%$ ．本均 $41.26 \%$ ナリキ。(第 11 表)

\section{第三項 仔蟲投與後 24 時間二於ヶル场合}

仔蟲投與後 24 時間二於テハ少ホ胃二最モ多ク發見シ。次二肺臟二比較的多數認 メ. 24 時間以前二比シ胃. 腸二於テ漸次減少/偭向キ示ス二反シ. 消化管以外，贜器- 
第 11 表 仔蟲投與後 10 時間二於ケル仔䖵發見率(家鬼)

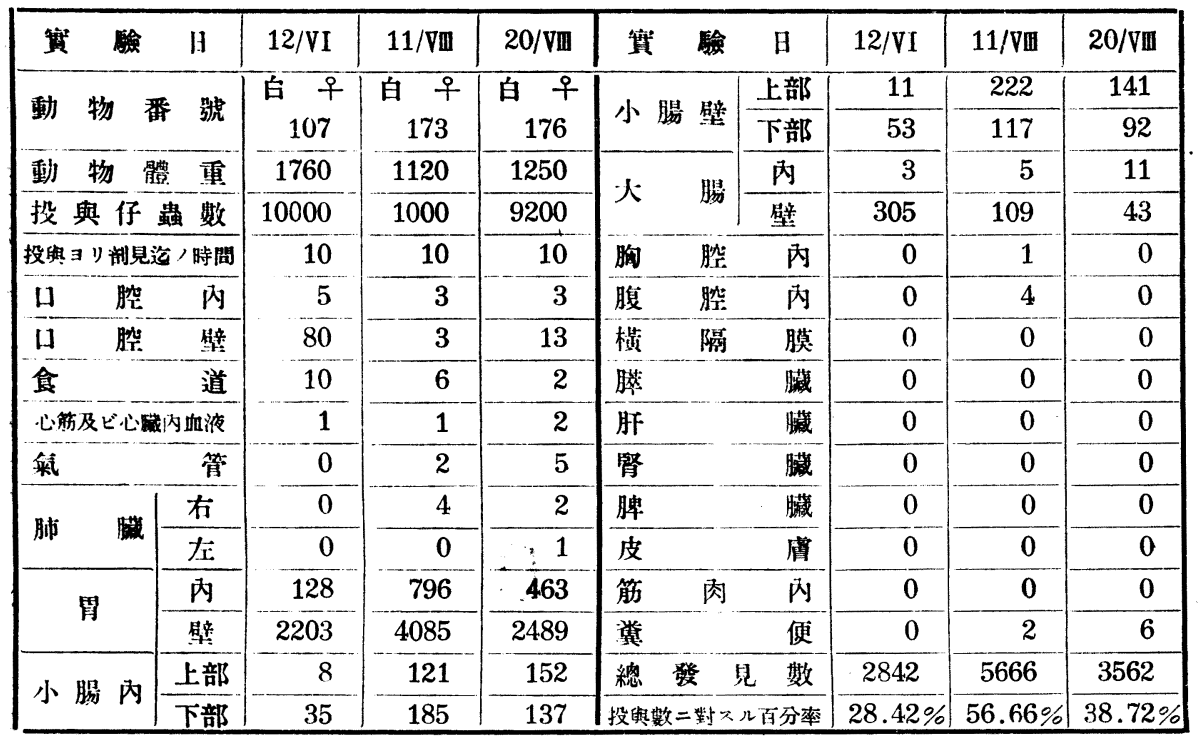

第 12 表 仔䖵投與後 24 時間二於ヶル仔蟲發見率(家鬼)

\begin{tabular}{|c|c|c|c|c|c|c|c|c|c|}
\hline 萁 驗 & $\mathrm{H}$ & $7 / \mathrm{VI}-8$ & $22 / \mathrm{VI}-23$ & $22 / \mathrm{VII}-23$ & 賽 & 日 & $7 / \mathrm{VI}-8$ & $\mid 22 / \mathrm{VI}-23$ & $22 / \mathrm{VII}-23$ \\
\hline \multirow{2}{*}{\multicolumn{2}{|c|}{ 動 物 番 號 }} & 白 우 & 白 令 & 白 + & \multirow{2}{*}{ 小腸 臂 } & 上部- & 7 & 110 & 53 \\
\hline & & 105 & 160 & 168 & & 下部 & 2 & 17 & 54 \\
\hline 動 物 骨 & 重 & 1770 & 1500 & 2000 & \multirow[b]{2}{*}{ 大 } & 內 & 36 & 5 & 10 \\
\hline 投興仔 & 數 & 10000 & 10400 & 8400 & & 壁 & 42 & 35 & 61 \\
\hline \multicolumn{2}{|c|}{ 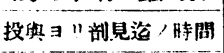 } & 24 & 24 & 24 & 胸 & 內 & 2 & 1 & 16 \\
\hline \multicolumn{2}{|c|}{ [1] 䑏 內 } & 5 & 17 & 3 & 腹 & 内 & 22 & 35 & 73 \\
\hline \multicolumn{2}{|c|}{ 11 脭 壁 } & 530 & 725 & 47 & 㮖隔 & 膜 & 36 & 43 & 59 \\
\hline 余 & 道 & 61 & 97 & 39 & 膵 & 臟 & 31 & 54 & 80 \\
\hline \multicolumn{2}{|c|}{ 心蔽及ビ心械为血液 } & 2 & 10 & 12 & 脬 & 臟 & 18 & 431 & 15 \\
\hline & 22 & 13 & 218 & 腎 & 臟 & 1 & 2 & 3 \\
\hline \multirow{3}{*}{ 肺䑏 } & 有 & 631 & 674 & 625 & 脾 & & 2 & 1 & 3 \\
\hline & T. & 516 & 616 & 343 & 皮 & 膚 & 3 & 37 & 3 \\
\hline & & & & & 肉 & 內 & 4 & 213 & 5 \\
\hline \multirow[t]{2}{*}{ 盟 } & 内 & 157 & 563 & 490 & 糞 & 便 & 21 & 28 & 19 \\
\hline & 壁 & 1335 & 1573 & 1037 & 子 & 宫 & & & 2 \\
\hline \multirow{2}{*}{ 小晹 队 } & 上部 & 4 & 34 & 10 & \multirow{2}{*}{\multicolumn{2}{|c|}{ 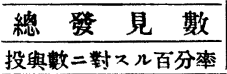 }} & 3492 & 5341 & 3292 \\
\hline & 下部 & 2 & 7 & 12 & & & $34.92 \%$ & $51.35 \%$ & $39.19 \%$ \\
\hline
\end{tabular}

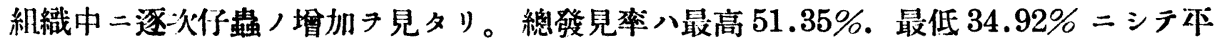
均 $41.28 \%+リ キ 。($ 第 12 表)

\section{第四項 仔题投與啳 48 時間二於ケル場合}

1子蟲投與後 48 時閒二於テハ. 總發見數ノ過半數ハ肺臟二於テ見ラレ. 次二發見率 
良好ナルモ/ヨリ列記スレバ冀便內. 胃. 食道. 口腔内. 筋肉. 横隔膜. 腹膑內. 心

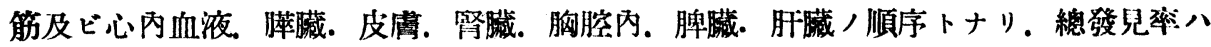
最高 $60.69 \%$ ．最低 $43.96 \%$ ニシテ．本均 $49.87 \%$ ナリキ。(第 13 表)

第 13 表 仔蟲投與後 48 時間ニ於々ル仔蟲發見率(策兔)

\begin{tabular}{|c|c|c|c|c|c|c|c|c|c|}
\hline 實 驗 & 日 & $27 / \mathrm{V}-29$ & $23 / \mathrm{VI}-25$ & $18 /$ VII-20 & 實 & 日 & $27 / \mathrm{V}-29$ & $23 / \mathrm{VI}-25$ & $18 /$ VII-20 \\
\hline \multirow{2}{*}{\multicolumn{2}{|c|}{ 動 物 番 號 }} & 鼠色 우 & 白 우 & 白 우 & \multirow{2}{*}{ 小晹 壁 } & 上部 & 33 & 42 & 7 \\
\hline & & 102 & 161 & 165 & & 下部 & 30 & 55 & 6 \\
\hline 動 物 & 曹 重 & 1750 & 1500 & 1800 & \multirow{2}{*}{ 大 } & 队 & 4 & 4 & 13 \\
\hline \multicolumn{2}{|c|}{ 投與 仔 蟲 數 } & 10000 & 10000 & 8900 & & 礕 & 20 & 12 & 12 \\
\hline \multicolumn{2}{|c|}{ 投與ヨリ剖見迄，時間 } & 48 & 48 & 48 & 胸 & 內 & 2 & 2 & 3 \\
\hline \multicolumn{2}{|l|}{ 口垫 } & 2 & 3 & 1 & 腹 & 內 & 2 & 10 & 27 \\
\hline \multicolumn{2}{|l|}{ 口腔 } & 76 & 378 & 11 & 橫 & 膜 & 3 & 59 & 32 \\
\hline \multicolumn{2}{|c|}{ 食 道 } & 84 & 300 & 204 & 膵 & 臟 & 4 & 9 & 3 \\
\hline \multicolumn{2}{|c|}{ 心筋及ビ心械內血液 } & 0 & 17 & 9 & 訮 & 䐬 & 1 & 1 & 2 \\
\hline & 268 & 2085 & 103 & 雵 & 蓝 & 0 & 8 & 1 \\
\hline \multirow{3}{*}{ 肺臓 } & 右 & 1280 & 1312 & 1478 & & & 1 & 2 & 2 \\
\hline & t & 1167 & 1220 & 1433 & 皮 & 膚 & 3 & 2 & 9 \\
\hline & 內 & 35 & 77 & 56 & 筋 & & 11 & 233 & 35 \\
\hline \multirow[t]{2}{*}{ 胃 } & $\mathrm{PS}$ & & & & 粪 & 便 & 950 & 20 & 321 \\
\hline & 壁 & 511 & 159 & 125 & 子 & 宮 & & 2 & 1 \\
\hline \multirow{2}{*}{ 小腸队丽 } & 上部 & 8 & 20 & 9 & 總 發 & 見 數 & 4496 & 6069 & 3912 \\
\hline & 下部 & 1 & 37 & 9 & \multicolumn{2}{|c|}{ 投與數二對ス几百分率 } & $44.96 \%$ & $60.69 \%$ & $43.96 \%$ \\
\hline
\end{tabular}

第二節 攝取後體內分布狀態卜各臟器卜八關係

\section{第一項 胃內容卜胃壁トニ於ヶル仔䗝ノ發見率}

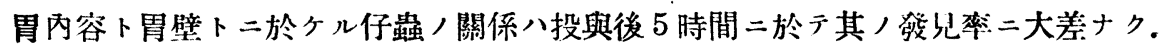

第 14 表 胃壁卜胃內餐二於 ケル仔蟲發見交

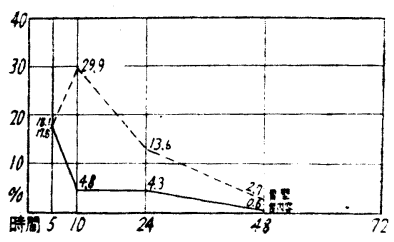

共 $=18 \%$ 前後き認メ. 10 時閒二於テハ胃壁二 $29.9 \%$

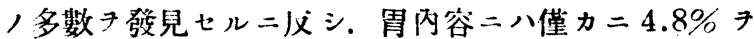
檢出セシノてナリ. 24 時間二於テ八兩者ノ差 $10 \%$ 內 外チ示シ. 48 時間二至りテ其ノ差接近シ $2.1 \%$ トナレ

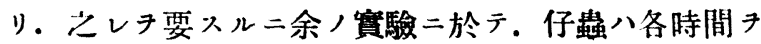
通ジ胃壁二多ク胃內容二少ナカリキ。之レナ曲線ニテ 示七バ第 14 表ノ如シ。

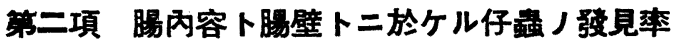

腸內容ト腸壁ト二於ケル仔蟲/關係八胃二於ケルト同樣腸壁二多ク腸內容二尠ナ シ. そレナ時間的二見レバ仔蟲投與後 5 時間二於テ其/差大約 $5 \%$ 示シ. 10 時間以

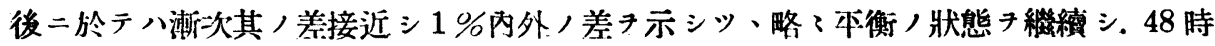


第 15 表 腸內容卜晹壁二於 ケル仔䗋發見䇣

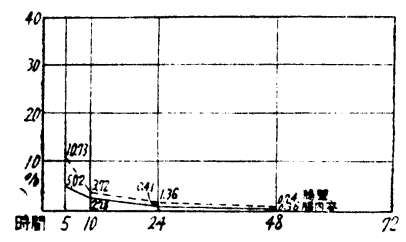

第 16 表 胃卜晹卜，關係

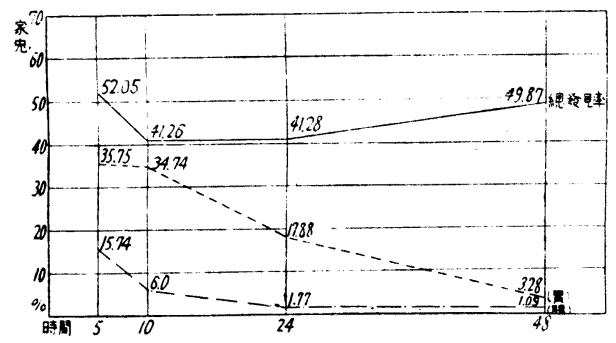

間二至リテ約 $0.4 \%$ 差キ示セリ. そレチ曲線ニテ示 七バ第 15 表ノ如シ。

\section{第三項 胃卜晹卜ニ於ケル仔浊ノ關係}

胃ト腸トニ於ケル仔蟲, 關係キ見ル二。胃二發見セ ラル、仔蟲八常二腸二於ケルモノヨリモ多數ニシテ。 そレキ時間的二見レバ投與後 5 時間二於テハ兩者ノ差 大約 $20 \%$ チ示シ. 10 時間二於テハ $28 \%$ ノ著差チ認メ. 爾後漸次低下シ. 48 時間二於テハ僅 カ $2 \%$ 差キ示ス二過ギズ. えレチ 曲線二テ示セバ第 16 表ノ如シ。

\section{药四項 肺蓝二於ケル仔䩶ノ}

\section{㓎見至}

肺藏二於テハ投與後 5 時間ニシテ 實驗 3 例中 2 例二於テ陽性ノ成績 得タリ、以上ノ實驗二依リ投與後 5

時間二於テ躰二仔蟲ハ肺臟二達シ得ル事ハ明ラカナリ。里見氏ノ實驗二依レバ投與後 6 時間二於テ經口. 經皮感染ノ何レ，場合二於テモモ陽性ナル事み報告セラレタリ。然レ ドモ. 其ノ數ニ於テハ僅少ニシテ同氏，投與後 6 時間二於ケル成績八 $0.2 \%$ ニシテ。 余ノ䐝驗二於テ八雨均 $0.18 \%+リ キ 。$

投與後 10 時間二於テモ僅カ二發罗セルノ 24 時間二至り其八數八俄然增加シ最高 $12.40 \%$ 。最少 $11.47 \%$ 。本均 $11.80 \%$ 認メ 48 時間二至り少其ノ數于增加シ左右兩肺藏二於テ最高 $32.71 \%$ 。最低 $24.47 \%$. 本均

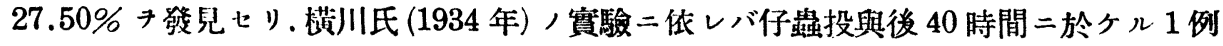
二於テハ肺藏內二 $=1.83 \% .1$ 例二於テハ $1.40 \%$ チ發兒セル二過ギズト云フ. 余ノ實驗 トハ甚ダシキ相違アリ。

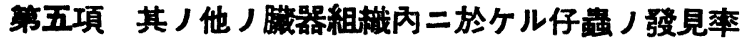

其八他，藏器. 組織二於テ投與後 10 時間迄二比較的多數き發見七シ部位八口腔. 食

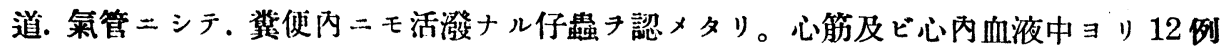
中 3 例陽性ニシテ總數ハ 4 隻ナリキ。24 時間二於テ口膑內二八依然トシテ多數ノ仔蟲

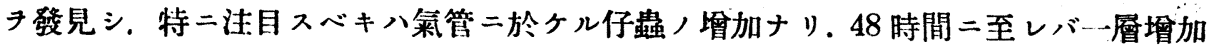
キ示セリ。消化管以外ニ於テモ仔蟲き認メ。之レテ列記スレバ肝藏. 膵藏. 腎臟. 脾 
藏. 筋肉. 皮蔳. 横隔膜. 腹腔內. 子宫. 冀便內等ニシテ何レモ陽性ノ成績キ得タリ。

\section{第三節 㾜理組織學的所見}

1）肺藏八肉哏的二表面本滑ニシテ色調一般ニ淡ナレドモ所々二謟赤色點狀ノ出血 斑き認ムルモノ多シ。えレ白鼠及ビ家鬼何レノ場合二於テモ投興後 24 時間以後ノ所 見ニシテ. 其レ以前二於テハ殆ンド正常ト變ル事ナシ。出血斑ノ部位キ切片標本トナ シ檢スル二肺胞壁細血管，擴大. 允血强ク。所々二出血部位アリ．肺胞內及ビ肺胞壁

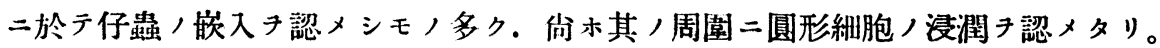

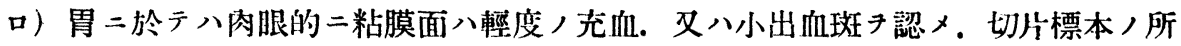
見八. 胃腺內二仔蟲, 穿入七ントスルモノ。 又八 24 時間以後二於テ既二深ク筋内㕣 內ニ入レルモノ等キ認メタリ。周圍二八輕度ノ浸潤タ認メシノミナリ。

八）腸二於テ八肉眼的二殆ンド變化ナク，切片標本，所見八腺膑内二正ニ入ラント

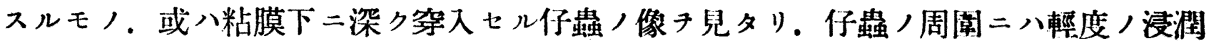
キ認メシモノ。或ハ認メザルモノアリテ. 特記スベキ變化キ認メズ。

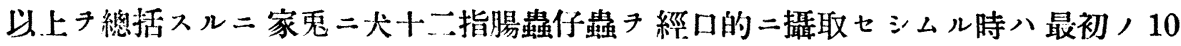
時間迄ハ上トシテ消化管內二見ラレ，沙化管以外二於テ發見七シ仔蟲ハ僅少ナリ。胃 二於テハ投與後 5 時間二於テ最モ多數ノ仔蟲尹認メ。爾後時閒ノ經過卜共二減少入.胃 內容卜胃壁卜，關係八胃壁二多ク．胃內容二尠ナシ。腸二於テモ投興後 5 時間二於テ 最モ發見率良好ニシテ以後渐次減少ス，腸內容卜腸壁卜，關係八腸憵二多ク．腸內容 二尠ナシ。投與 24 時間以後二於テ肺臟二多數, 仔蟲 認メ. 其, 他, 贜器. 組織內二 於テモ比較的多數, 仔蟲尹認メタリ。各藏器二於ケル組糡學的所胃八肺藏二於テ所々

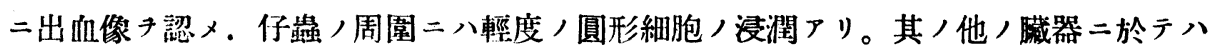
仔蟲ノ周圍二輕キ浸潤キ認メシ以外特記スベキ變化キ認メザリキ。

\section{第五章 總括站二考按}

經口的二非固有宿主動物二投與セラレタル仔蟲ノ運命二就テ追究セリ。

投與後 10 時間迄八白鼠及ビ家鬼何レノ場合ニ於テモ仔蟲八まトシテ消化管內二見 ラレ.特二胃璧. 胃内容中二其ノ大部分タ發見シ. 24 時閒二於テ胃ニ八著明ノ減少タ示 シ. 其ノ過牛數ハ肺臟二認メラレ。此,頃 $コ$ 各組織臟器內二仔蟲 $尹$ 認メシモノ多ク

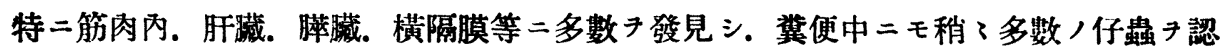
メタリ. 松猗氏 (1937 年)八白鼠，實驗二於テ經口的感染，場合. 投與數／約牛數八其 
ノ儘腸管キ下リテ排泄サレ. 殘リノ仔蟲ハ肝臟。心臟. 肺臟キ經テ氣管二至リ２4乃 至 42 時間ニシテ洇喉頭二達シ.周喡ノ筋肉二侵入シ. 仔蟲ノ大部分ハ $5-6$ 日ニシテ

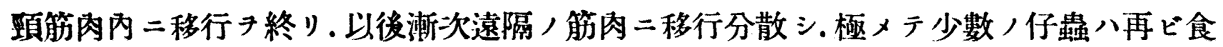
道キ下リテ腸管二至ル。投與後 185 日ノモノ二於テモ $46 \%$ 發見セリト述心゙ラレタリ。

余ノ短時日ノ賽驗二於テ八筋肉內及ビ冀便內二同氏ノ云ハル、ガ如キ多數ノ仔蟲 認ムル事キ得ザリキ，郎チ家鬼ノ璝驗二於テ筋肉內二檢出セラレシ最高發胃率八投與

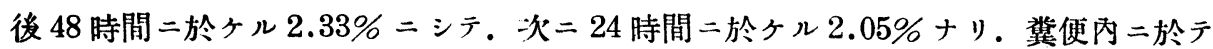
モ比較的多數キ認メタレドモ。「プロセント」き左右スルガ如キ多數ノ仔蟲キ發見スル テ得ザリキ. 24 時間. 48 時間二於テ口膑壁二仔蟲ノ增加テ示セル八. 肺臟き通過七 ル仔蟲ガ氣管. 喉影き經テ、上昇セルタメナルベシ。

肝藏二於テ最高發罢率八 24 時閒二於ケル $4.14 \%$ ニシテ.夫レ以外ノ時閒二於テハ 發見數極メテ尠ナシ. 其ノ他楛隔膜. 腹腙內. 膵臟. 皮膚等二於テ比較的多數ノ仔蟲 キ認メ. 性器二於テモ 3 例ノ陽性成續得タリ。故二經口的二攝取セラレタル仔蟲八 24 時間以後二於テアラュル臟器. 縕織ニ達スル事チ得ベク. 性器二迄到達七ル仔贵ハ 其ノ動物奷娠中ナル時ハ胎盤キ通り胎兒へ迄至リ、生前感染可能ナリ。

各臟器內二侵入セル仔蟲ノ分雌試驗ハ各時間き通ジテ肺藏二發見七ラル、仔蟲數最 モ多ク．腸管及ビ肝蔵之レニ次ギ，胃二於テ最モ不良ナリ。之レ胃二於テ仔蟲穿入二 最モ好條件ナルチ思ハシメ、肺藏二於テ仔䖪, 通過容易ナルチ思ハシム。

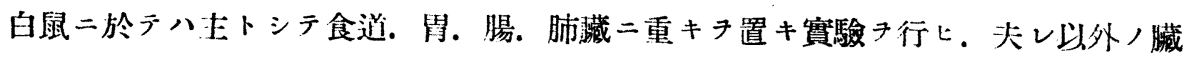
器. 縕織ハ一區分トシテ操作セル關係ト各臟器別二詳細ナル報告ノ出來ザルハ甚ダ遺 㥓トスルトコロナリ。

家鬼二於テ胃內容ト胃壁卜ノ關係ハ常二胃壁二多數ノ仔蟲キ認メ.最高發見率ハ 10 時間二於ヶル $29.98 \%$ ニシテ.胃內容二於テハ 5 時間二於テ $18.11 \%$ 最高雍テ示シ爾 後時間ノ經過卜共二低下ス。腸二於ケル壁ト內容トノ關係ハ僅カノ差ナレドモ腸壁二 多ク.腸內容二卙ナシ. 總役見率ヨリ見ルモ腸二發見セラル、仔䖵數ハ投與數ノ數「プ ロ七ント」二過ギズ. 顀便內二於テモ發見率キ左右スルガ如キ多數ノ仔蟲ハ認メザリ キ. 故二經口的二攝取セラレタル仔蟲ハ投與後 10 時間頃ヨリ盛ン二胃壁二穿入シ. 一部ハ腸壁ヨリ血行淋巴道キ介シテ心臟チ經テ肺藏二至リ、爾後氣管.喉頭キ經テ筋肉

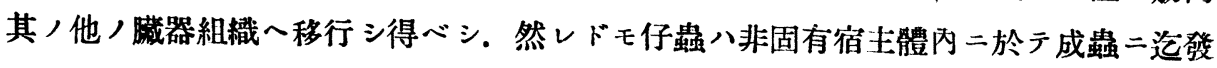
育スル事キ得ザルョ以テ早晚死隇シ得ベキ運命二在リ。郎チ其ノ一部八䔬便ト共二排 泄サレ，其ノ過牛數ハ宿圭ノ臟器. 組織內ニテ死隇組織化スモノナルベシ。 


\section{第六宰 結 論}

1）犬十二指腸蟲成熟仔蟲于 經口的二非固有绾ま二與フル時ハ投與後 24 時間以前 二於テハ主トシテ消化管內二發見サレ. 24 時間以後ハ肺臟. 氣管. 咽喉. 食道. 心筋

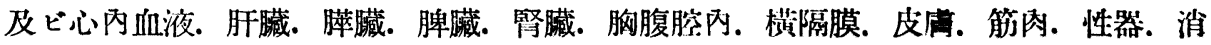
化管及ビ䔬便內等二於テ發見セリ。

2) 肺臟二發見七ラレシ仔蟲數八投與後 24 時間二於テ白鼠二於テハ左右兩肺臟ヨ リ本均 $15.6 \%$ チ認メ。同時間二於テ家鬼ヨリハ本均 $11.8 \%$ テ發見 シ. 48 時間二於テ 八本均 $27.5 \%$ 檢出セリ。

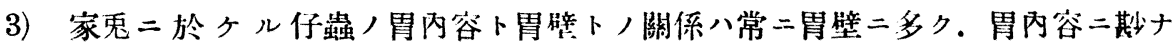
シ。

4）仔蟲ノ腸內容ト腸壁卜ノ關係モ腸壁二多ク腸內容二尠シ。

5）余ノ實驗二於テ數例性器二仔蟲于發罗セリ。

6) 各臟器片， Baermann 氏裝置應用，分噰試驗二於テ分雖良好ナルモノヨリ順 次二列記スレバ肺臟. 腸管. 肝藏. 胃ノ順序トナレリ。

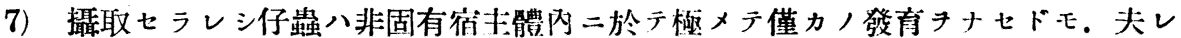
以上ノ發育キナサズ。

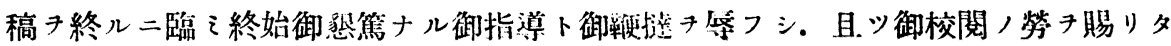
ル恩们宮川敎授二對シ深甚ナル感謝ノ意キ表ス。

\section{主要文酮}

1) Augustine D., Experiment on the length of infective hookworm in soils. Amer. Journ. of Hyg. Vol. 2. No. 2. $19 k 2$.

2) Ackert and Payne, Studies on the occurence distritution and morphology of Necator suillus, including description of the other species of Necator. Amer. Journ of Hyg. Vol. 3. No. 1. 1923.

3) Cort. W. C., Investigation on the control of hookworm disease I) General introduction. Archiv. f. Schiffs- u. Tropen-Hyg. Bd. 26. 1922.

4) Cort W. W. and Ackert, J. E., Investigation on the control of hookworm disease. II) The des:ription of an apparatus for isolating infective hookworm larve from soil. The Amer. Jour. of Hyg. Vol. 2. No. 1. 1922.

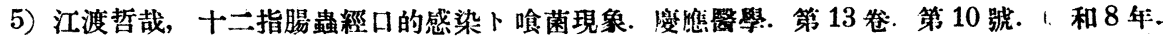

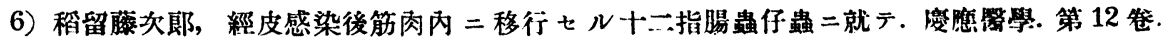
第 3 號. 炤和 7 年.

7）江口季雄，十二指腸䖵仔蟲，暴種動物組織內侵入二就テ.日本病理學會雜誌. 第 12 年. 


\section{大正 11 年.}

8）江口季雄, 十二指晹蛊二關スル研究. 愛知露學. 第 29 卷. 第 6 號. 大正 11 年.

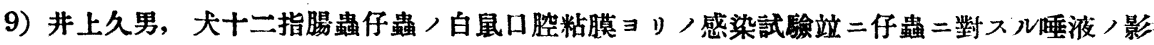

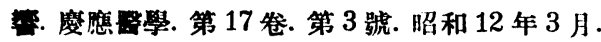

10) Foster, A. O., The immunity of dogs to Ancylostoma caninum. Amer. Journ. Hyg. Vol. 22. p. 65-105. 1935.

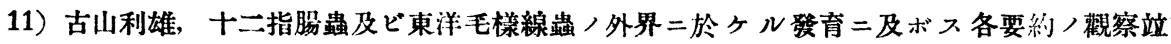
二兩種感染仔蟲/生㮩二就テ. 朝鮮䃜學會雜誌. 第 23 卷. 第 4 號. 昭和 8 年 4 月.

12) Fulleborn, Methode zur Anreichung von Ancylostoma. Archiv. f. Schiff. u. TropenHyg. Bd. 15. 1911.

13) Fülleborn, Über “Taxis', (Tropismus) bei Strongyloides u. Ancylostomalarven. Archiv. f. Schiff. u. Tropen- Hyg. Bd. 28. 1924.

14) Fülleborn, UUber die Anpassung der Nematoden an den Parasitismus und den Infectionsweg bei Askaris und anderen Fadenwürmen des Menschens. Archiv. f. Schiff. u. Tropen- Hyg. Bd. 24. 1920.

15) Fülleborn, Nachweis von Ancylostomen und Strongyloides durch Plattenkotkultur. Archiv. f. Schiffs u. Tropen- Hyg. Bd. 25. s. 121. 1921.

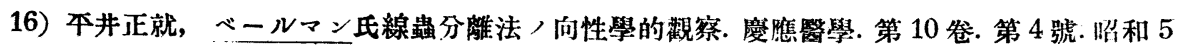
年 4 月.

17）平井正就，十二指腸蟲被胞仔蟲，向性(トロピスムス)二就テノ研究站二其他／生物學的 知見補遗. 度憵淟學. 第 9 卷. 第 2 號. 胎和 4 年 2 月.

18) Kofoid. C. A. \& Barber, M. A., Rapid method for detection of ova of intinal parasites in human stools. Archiv. f. Schiffs u. Tropen-Hyg. Bd. 23. 1919.

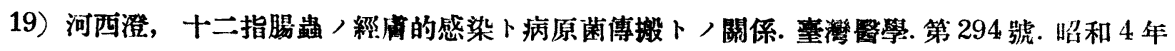
9 月.

20）熊谷已三郎，十二指腸䖵仔蟲，經皮感染二因ル氣管喉頭及ビ咽頭領域二於ヶル病理學的

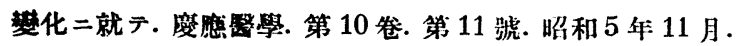

21）神岡精一，經口的感染二於ヶル大十二指腸蟲仔蟲，非固有宿士(白鼠)體內移行二就テ. 日本寄生蟲學會記事. 咍和 12 年.

22）小林英一，「アンキロストーマ」咸各種感染仔蟲卜「カトール・アメリカーヌス」感染

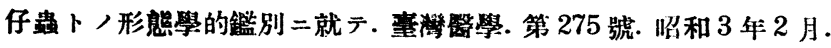

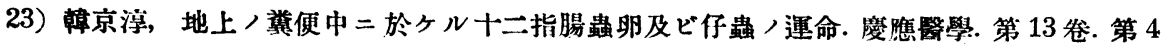
號. 昭和 8 年.

24) Looss, A., The anatomy and life history of Agchylostoma duodenale, Dub. Records of the school of medicine. Vol. 3. 1905. and. Vol. 4. 1911

25) Lane, Clayton, The mass diagnostic of hookworm infection. Amer. Journ. Hyg. Vol. 8. May. p. 1-148. 1928.

26) McCoy, O. R., The influence of temperature, hydrogen-ion concentration and oxygen tension on the development of the eggs and larvae of the dog hookworm Ancylostoma caninum. Amer. Journ. Hyg. Vol. 11. p. 413-448. 1930. 


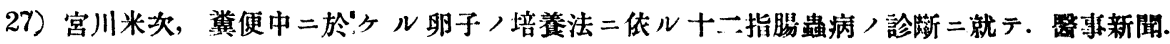
第 874 號. 大正 2 年.

28）宮川米次，十二指腸蟲仔蟲，一新集聚法二就テ. 嘼事新聞. 第 899 號. 大正 3 年.

29）松崎義周，非固有宿寺體內二於ヶル犬钩蟲柋染仔䖵，運命. 日本寄生䖵學會記事. 昭和 $1:$ 年.

30）松崎義周，「アンキロストーマ」種及ビ「ネトール」種十一指晹䖵卵站二東洋毛栐線蟲卵

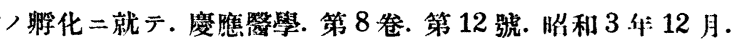

31.）松浦錨式，十二指晹蟲症，實驗的研究. 病理學紀要. 第 7 尞. 第 5 號. 炤和 6 年.

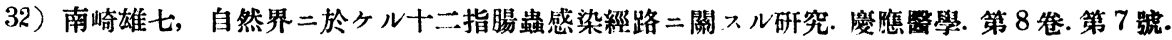
沼和 3 年 7 月. -

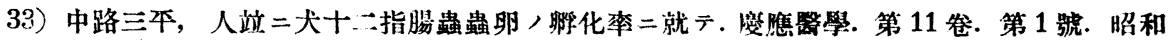
6 年.

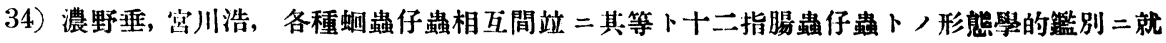
テ. 漫礁擎學. 第 9 卷. 第 9 號. 和和 4 年 9 月.

35）內藤和行，十二指腸蟲，發育二及ボ入.寒冷，影響二就テ. 東京繁事新誌. 第 2580 號. 昭 和 3 年.

36）大本得三，十二指腸䖵及「ストロンギロイデス」培養試驗ニ於ヶル錯誤站二其ノ原因. 東 京䝷事新誌. 第 1887-1889 號. 大正 3 年.

37) Rockefeller-foundation, International health board. Archiv. f. Schiffs u. Tropen-Hyg. Bd. 26. s. 126-127. 1922.

38) Rotter, W., Über die histologischen Veränderungen des Dünndarms bei Ancylostomiasis. Zentralbl. f. Bact. Ref. Bd. 106. s. 229. 1932.

39) Shelmire, B., Experimental creeping eruption from a cat and dog hookworm. Zentralbl. f. Bact. Ref. Bd. 94. s. 174. 1929.

40) Scott, J. A., An experimental study of the development of Ancylostoma caninum in normal and abnormal host. Amer. Journ. of Hyg. Vol. 8. No. 2. 1928.

41) Scott, Allen, J., The length of specimens of the dog hookworm after various meth ods of fixation. Zentralbl. f. Bact. Ref. Bd. 100, s. 134. 1931.

42) Sarles M. P., Development of an aquired resistance in rabbits by repeated infection with an intestinal nematode. Journ. Paresit. Vol. 19. 1932.

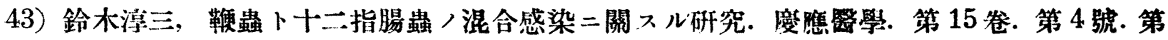
7 號. 炤和 10 年.

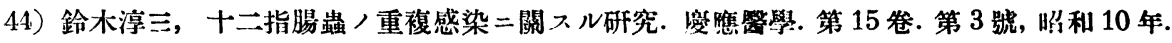

45）鈴木慧二., 十指腸䖵病二關スル研究 (仔蟲 $/$ 皮層侵入二就テ). 日本病理學會雜誌. 第 12 年. 大正 12 年.

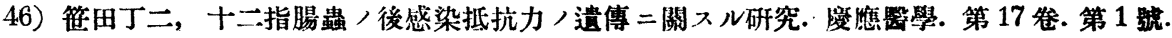
昭和 12 年.

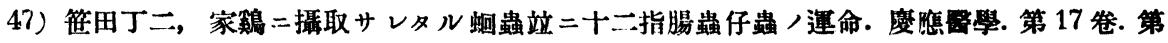
3 號. 昭和 12 年.

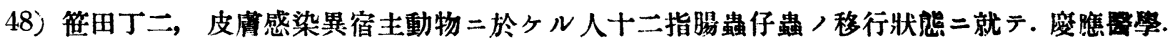


第 15 卷. 第 12 號. 昭和 10 年.

49）笹田丁二，人十二指腸蟲／遗傳免疫二關スル研究. 日本笴生蟲學會記事. 詔利 11 年.

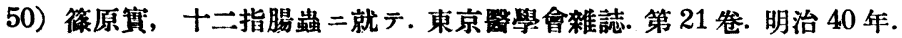

51）佐藤千代三郎，Vitamin A 缺乏白鼠二於ヶ $ル$ 犬十二指腸蟲/經口的感染試驗. 日本知生 贵學會記事. 咍和 12 年.

52）里見䓠一郎，異宿主動物體內二侵入七ル十二指䏮蟲仔蟲，運命二關スル筫驗的研究（第 一報告). 日本奇生蟲學會記事. 眳和 12 年.

53）田中正鐸，日本二於ヶル十二指晹小鈎口蟲及ビ其/疾患. 東京醫學會雜誌. 第 21 卷. 第 18 明治 40 年.

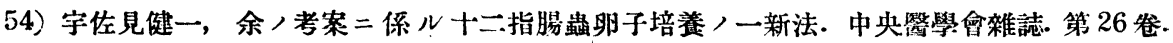
第 5 號. 大正 8 年.

55）吉田貞雄, 松下正信, 門䮶健次，日本，炭坑夫ノ十二指腸蟲症二就キテ. 日本學術協會 報告 4. 炤和 3 年.

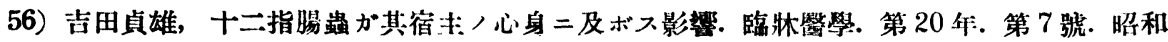
7 年 7 月.

57）吉田貞雄, 門馬健次，十二指晹䖵病卜鐄川. 大阪醫學會雜誌. 第 24 卷. 第 2 號. 第 10 號. 大正 14 年.

58）吉田貞雄，經口的二柋染セル十二指晹蝹幼䖵及ビ「ストロンギロイデス.フィラリア」蟲型 幼蟲ノ宿主體內移行ノ一新經路二就テ. 東京醫事新誌. 第 2088 號.

59）橫川定, 十二指晹蟲，防遏二關スル基礎的研究. 特二同仔蟲，生物學的知見二關スル近 業. 日新醫學. 第 16 年. 第 10 號. 昭和 2 年.

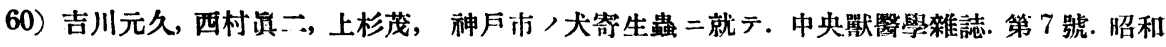
11 年.

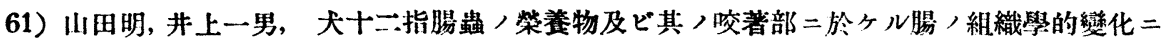

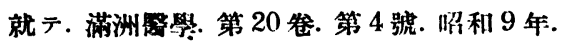

